\title{
Composition Variation and Eruption Dynamics of the El Cajete Series, Valles Caldera, New Mexico
}

\section{Minghua Ren ${ }^{1^{\star}}$ and Don F. Parker ${ }^{2,3}$}

${ }^{1}$ Department of Geoscience, University of Nevada Las Vegas, Las Vegas, NV 89154, USA

${ }^{2}$ Department of Geosciences, Baylor University, Waco, TX 76798, USA

${ }^{3}$ School of Math and Science, Wayland Baptist University, Plainview, TX 79072, USA

\begin{abstract}
The youngest eruptions in the Jemez Volcanic field occurred in the southwestern moat of the Valles Caldera, producing two series: a younger El Cajete series (ECS) with lower $\mathrm{SiO}_{2}(72-76 \mathrm{wt} \%)$, consisting of three members; in ascending order: the El Cajete Pumice Fall (ECP), Battleship Rock Tuff (BAT), and Banco Bonito Lava Flow (BB); and an older South Mountain Rhyolite with higher $\mathrm{SiO}_{2}$ (76-79 wt\%). Petrological, mineralogical, and geochemical data show that SMR and ECS belong to two different magmatic systems. ECS came from a hotter, less silicic, deeper magma chamber. Mineral equilibria calculations indicate that the ECS formed over a pressure interval of $\sim 2.52-3.68 \mathrm{kbar}$ and a temperature range of $\sim 834$ to $868^{\circ} \mathrm{C}$; SMR yielded a lower, narrower pressure range of about $1.24 \mathrm{kbar}$ and a lower equilibration temperature of $\sim 728-736^{\circ} \mathrm{C}$.
\end{abstract}

The dynamic difference of the eruptions caused the ECS to have a reverse compositional zonation. With increasing silica in ECP--BAT-BB, whole-rock trace elements show the following changes: $\mathrm{Rb}$ increases, $\mathrm{Nb}$ slightly increases, whereas commonly incompatible elements, such as $\mathrm{Sr}, \mathrm{Ba}$, and $\mathrm{Zr}$, decrease. A moderately-deep subjacent magma chamber developed under the caldera and the magma built the compositional gradients during a low energy episode in the chamber. Magma recharge induced the eruption of ECS. Chemical variations in the different members of ECS correlated with the changing eruption energy. The strongest early eruption tapped into the deeper part of magma chamber and caused mixing of different chemical zones in the magma. Later eruptions were less energetic and only released the more felsic melt from the upper part of the magma chamber.

\section{Introduction}

The El Cajete Series is the youngest product of the well-known, silicic, resurgent Valles Caldera of the Jemez Mountains in northern New Mexico. The Jemez Volcanic Field evolved over the past $16 \mathrm{Ma}$ [1]. The magma system of the Valles caldera complex formed at the intersection of Jemez Lineament and Rio Grande Rift, produced two major caldera-forming eruptions, which formed the lower and upper Bandelier tuffs at, respectively, 1.61 and $1.22 \mathrm{Ma}$ [2-7]. Following the eruption of upper Bandelier Tuff and the formation of the Valles Caldera, a series of rhyolite domes, the Valles Rhyolite Formation, erupted from ring fracture vents in the Valles Caldera at 1.1 Ma and extended over a 0.7 m.y. interval $[8,9]$. The most recent eruptions of the Valles Caldera produced the South Mountain Rhyolite (SMR), 507 $\mathrm{Ma}$ [2] to $521 \mathrm{Ma}$ (39Ar /40Ar) [10], and the El Cajete Series (ECS), 50 to $60 \mathrm{ka}$ [11-14] at the southwestern moat of the Valles Caldera (Figure 1). New 40Ar/39Ar sanidine single crystal ages indicate that ECP and BAT erupted at $74.4 \pm 1.3 \mathrm{ka}$ and BB erupted at $68.3 \pm 1.5 \mathrm{ka}$ [15].

South Mountain rhyolite crops out along the southern margin of the caldera. The three El Cajete members were the products of a long eruptive sequence. The stratigraphic relationships among the ECS are, from the oldest to the youngest, El Cajete Pumice Fall (ECP), Battleship Rock Tuff (BAT), and Banco Bonito Lava Flow (BB) [1618]. ECS has lower silica rhyolite $\left(\mathrm{SiO}_{2}\right.$ 72.04-75.29 wt\%) compared with SMR ( $\mathrm{SiO}_{2}$ 76.3-79.25 wt\%) (Table 1) (Supplementary File). The three members show only slight compositional variation. The El Cajete pumice (ECP) erupted first, forming Plinian style pumice fall and associated pyroclastic flow deposits [16] has lower $\mathrm{SiO}_{2}(72.28$ 73.88); Banco Bonito lava (BB) the youngest member in the series [17] has higher $\mathrm{SiO}_{2}$ (73.08-75.94).
The energy and the areal distribution of ECP were the largest in the whole series. The newest estimated volume of the ECP is about 7.6 $\mathrm{km}^{3}$ dense rock equivalent (DRE) [18] (much larger than the previous $1.3 \mathrm{~km}^{3}$ DRE [16,19]). Battleship Rock Tuff (BAT) (DRE $3 \mathrm{~km}^{3}$ ) was formed by a series of pyroclastic flows erupted from a vent near El Cajete Crater [20]. After the eruption of the BAT, there was a lull of around $6 \mathrm{ka}$ and the surface of BAT was eroded [15]. The BB later filled some of these gullies over BAT $[16,18,19,21]$. The BB is a porphyritic glassy flow that erupted from a vent located $1 \mathrm{~km}$ northwest of the $\mathrm{El}$ Cajete Crater. According to the extent and thickness of the flow, the volume of the Banco Bonito is estimated $4 \mathrm{~km}^{3}$ DRE [19].

This paper discusses geochemical variation within the ECS. Using phenocryst compositions and geothermometry and geoberometry, this paper will also discuss the possible geothermal condition of ECS and SMR. ECS formed from a deeper and less silicic chamber. There are reversed compositional gradients in the three members. The early eruption has a lower silica composition and the latest one has the highest silica. Trace elements show the more detailed change. Eruption dynamics caused the ECS to be erupted in a reversed compositional sequence.

"Corresponding Author: Dr. Minghua Ren, Department of Geoscience, University of Nevada Las Vegas, Las Vegas, NV 89154, USA; E-mail: minghua.ren@unlv.edu

Citation: Ren M, Parker DF (2019) Composition Variation and Eruption Dynamics of the El Cajete Series, Valles Caldera, New Mexico. Int J Earth Environ Sci 4: 163. doi: https://doi.org/10.15344/2456-351X/2019/163

Copyright: (C) 2019 Ren et al. This is an open-access article distributed under the terms of the Creative Commons Attribution License, which permits unrestricted use, distribution, and reproduction in any medium, provided the original author and source are credited. 


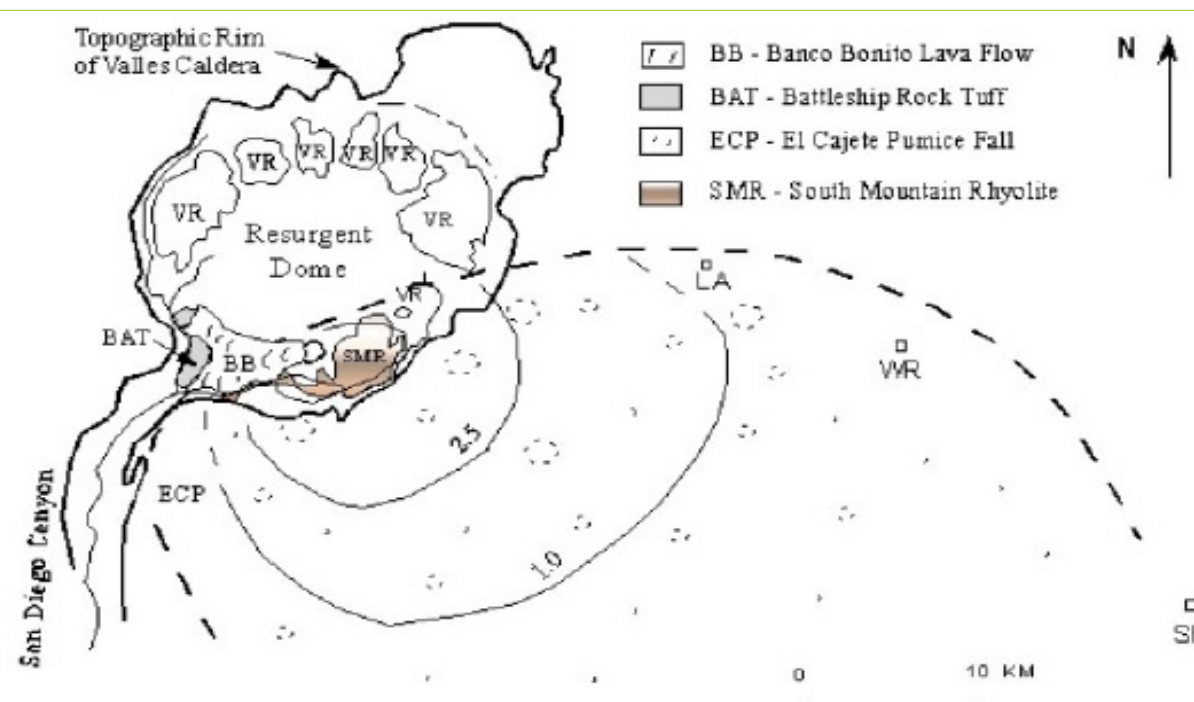

Figure 1: Geologic map of the Valles Caldera. The youngest eruptions occurred in the southwestern moat of the caldera. South Mountain Rhyolite (SMR) is the youngest rhyolite dome of the Valle Grande Member. El Cajete Series consist of three members: El Cajete Pumice Fall (ECP), Battleship Rock Tuff (BAT), and Banco Bonito Lava Flow (BB). Thickness of El Cajete Pumice is shown in the isopach map. L.A., Los Alamos; W.R., White Rock; S.F., Santa Fe; VR, undifferentiated Valle Grande Member rhyolite domes [10,16].

\section{Sampling and Methods}

Forty one rock samples were collected from three different units: Bandelier tuff (4), South Mountain Rhyolite (SMR) (10), and El Cajete Series (ECS) (27). Within the ECS, nine samples were taken from El Cajete Pumice Fall (ECP) deposit (all pumice), twelve from the Battleship Rock Tuff (BAT) (nine pumice and three welded tuff), and seven from the Banco Bonito Lava Flow (BB) (all vitrophyre).

Electron microprobe analyses were made of all phenocryst phases and some glass. Analyses were performed on a Cameca Camebax electron microprobe at Baylor University and JEOL JXA8900 at University of Nevada Las Vegas. Operating conditions were: $15 \mathrm{kV}$ accelerating voltage, emission current of $10 \mathrm{nA}$ for feldspar and $15 \mathrm{nA}$ for other minerals, spot sizes are $10 \mu \mathrm{m}$ for feldspar and $3 \mu \mathrm{m}$ for other minerals. Standards were appropriate silicates and oxides.

Whole-rock major and selected trace elements were analyzed at Baylor University by wavelength-dispersive XRF. A tungsten-carbide shatterbox was used to powder the samples. Six grams of the powder were combined with one gram of bakelite and then compressed into a pellet. Pellets were put into an oven to heat for half an hour at 115 oC. The average standard deviation for BBB is mostly less than $2 \%$ for major elements and less than $10 \%$ for trace elements. REE INAA analysis was performed by Activation Laboratories, Canada.

\section{Results and Discussion}

\section{Petrography}

\section{El Cajete Pumice Fall (ECP)}

ECP pumice contains phenocrysts of plagioclase 10-15\%, quartz $5-8 \%$, amphibole $2-3 \%$, and biotite $3-5 \%$. The plagioclase is white, about 1-2 mm in length, and mainly subhedral. The quartz is colorless, granular, and 1-2 mm in diameter. Amphibole is needle-shaped, euhedral, black or dark green color and about 1-3 $\mathrm{mm}$ in length. Biotite is sheet-shaped, black color, and 1-2 mm in diameter. Because the pumice is very soft, no thin sections were prepared for them.
Partly resorbed plagioclases in ECP contain glass. The glass in plagioclase contains gas cavities (Figure 2a). A SEM image shows the boundary between plagioclase and glass in Figure 2b. There are large gas cavities in the pumiceous glass and some gas bubbles in plagioclase. The gas bubbles in glass within plagioclase show some connection channels with the surrounding glass (Figure 2b).

\section{Battleship Rock Tuff (BAT)}

BAT consists of three zones: a lower unwelded zone, middle welded zone, and upper unwelded zone. In the lower and upper zones, unsorted pumices are scattered in an ashy matrix. The color of the Battleship Rock tuff pumices is usually yellowish brown, and the core of large pumices (10-20 cm in diameter) is gray. The phenocrysts in the pumice are plagioclase $5-8 \%$, hornblende $1-2 \%$, biotite $1 \%+$, clinopyroxene $<1 \%$, orthopyroxene $<1 \%$, magnetite and ilmentite $<1 \%$, quartz $1 \%+$, and a few grains of sanidine.

The plagioclases are mainly subhedral, $1-3 \mathrm{~mm}$, compositionally zoned. Most plagioclases have normal zonation, some with reversezoned rims. The hornblendes are euhedral, $0.1-0.3 \mathrm{~mm}$, most of them occurring as isolated grains, but some occur as mantles over clinopyroxene and biotite. Clinopyroxenes are mainly euhedral, 0.1 - $0.3 \mathrm{~mm}$ (Figure 3a). Most biotites have hornblende overgrowths (Figure $3 \mathrm{~b}$ ). There are plagioclase, biotite, hornblende aggregates in the rock. The crystal size of plagioclase $(<1 \mathrm{~mm})$ in the aggregates is smaller than most isolated plagioclase grains.

\section{Banco Bonito Lava Flow (BB)}

BB is largely vitrophyric. The color of the rock is glassy black. The phenocrysts are flow aligned and make up about 16 volume percent of the rock. The phenocrysts are plagioclase $8-10 \%$, quartz $2-3 \%$, biotite $1 \%+$, clinopyroxene and orthopyroxene $<1 \%$, hornblende $2-3 \%$, and $<1 \%$ opaque minerals.

The plagioclases are mostly subhedral. Most of the plagioclases are normally zoned, some with reverse-zoned rims. Some of them have resorbed cores but glass-free rims (Figure 4A). The resorption of 
Citation: Ren M, Parker DF (2019) Composition Variation and Eruption Dynamics of the El Cajete Series, Valles Caldera, New Mexico. Int J Earth Environ Sci 4: 163. doi: https://doi.org/10.15344/2456-351X/2019/163
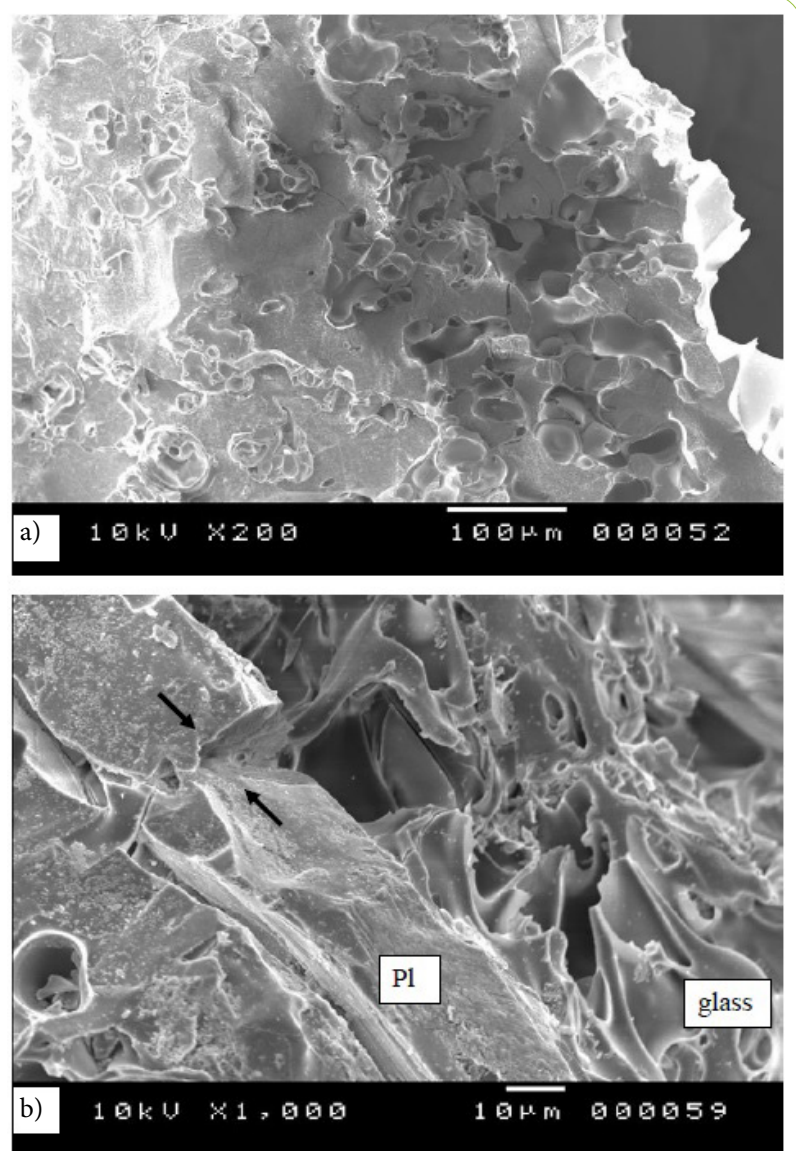

Figure 2: Plagioclase image from Scanning Electron Microprobe. a). There are gas cavities in the resorbed glass. Gas in glass escaped during the eruption.

b). Boundary between plagioclase and pumiceous glass. There are large gas bubbles in glass, and the cavities in plagioclase are connected with gas bubbles in surrounded glass. $\mathrm{Pl}=$ glass, $\mathrm{gl}=$ glass .

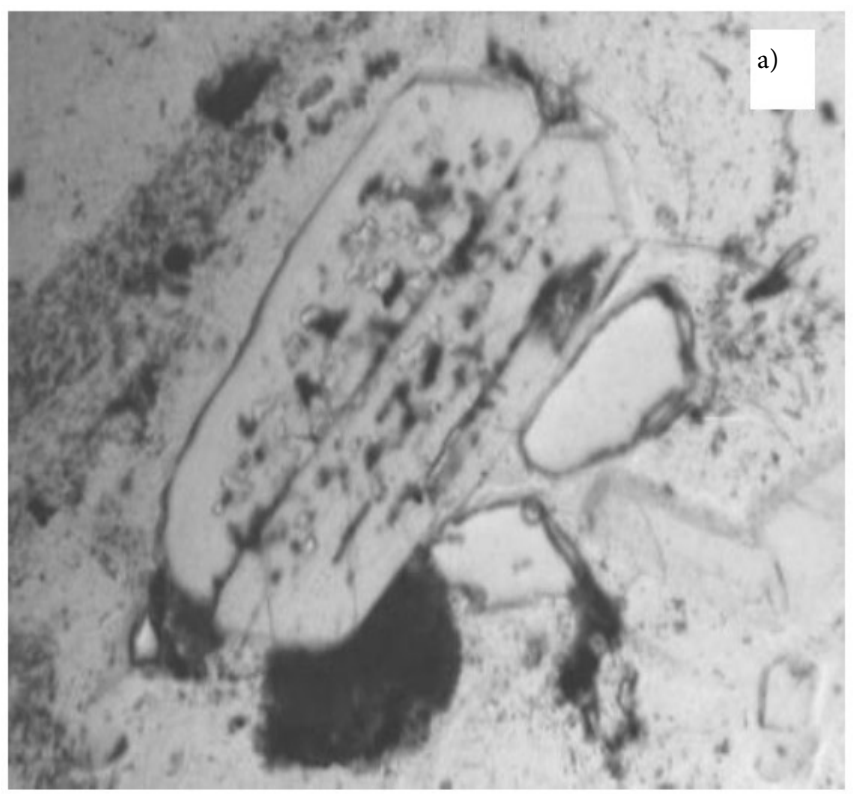

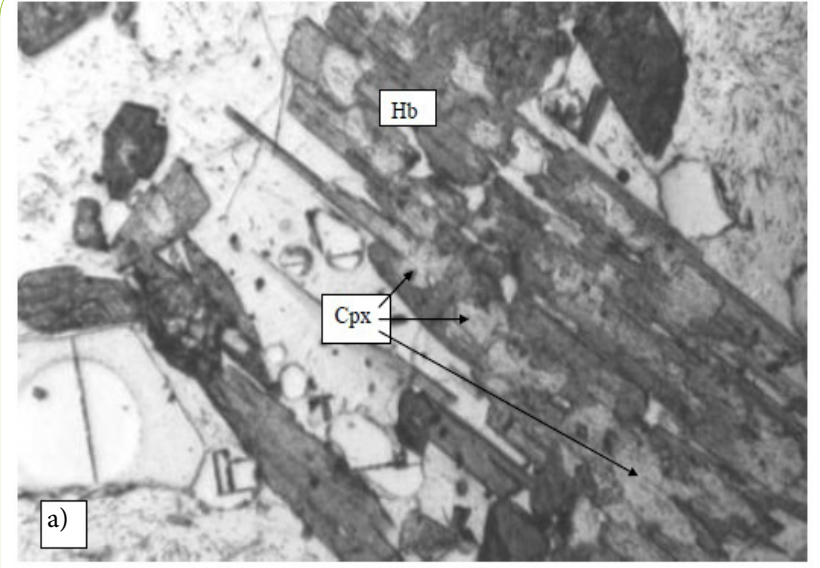

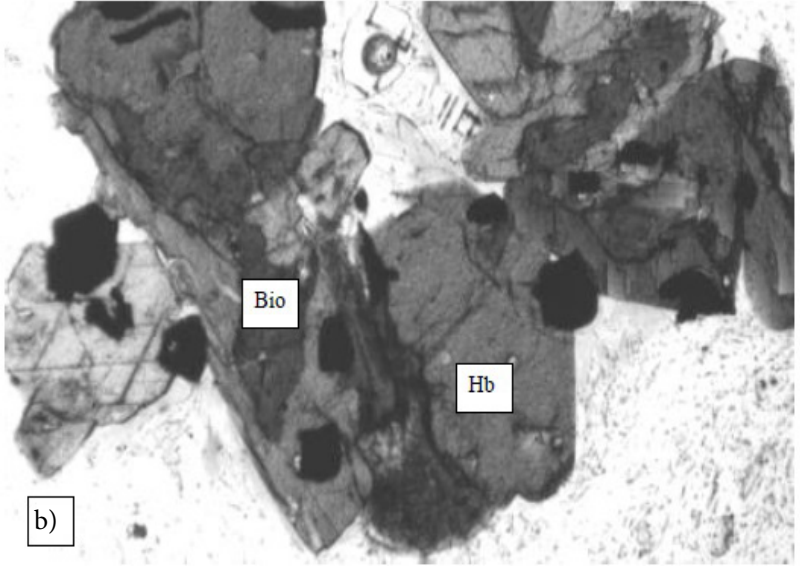

Figure 3: Hornblende overgrowths on phenocrysts in Battleship Rock tuff.

a). Clinopyroxene mantled by hornblende.

b). Biotite mantled by hornblende.

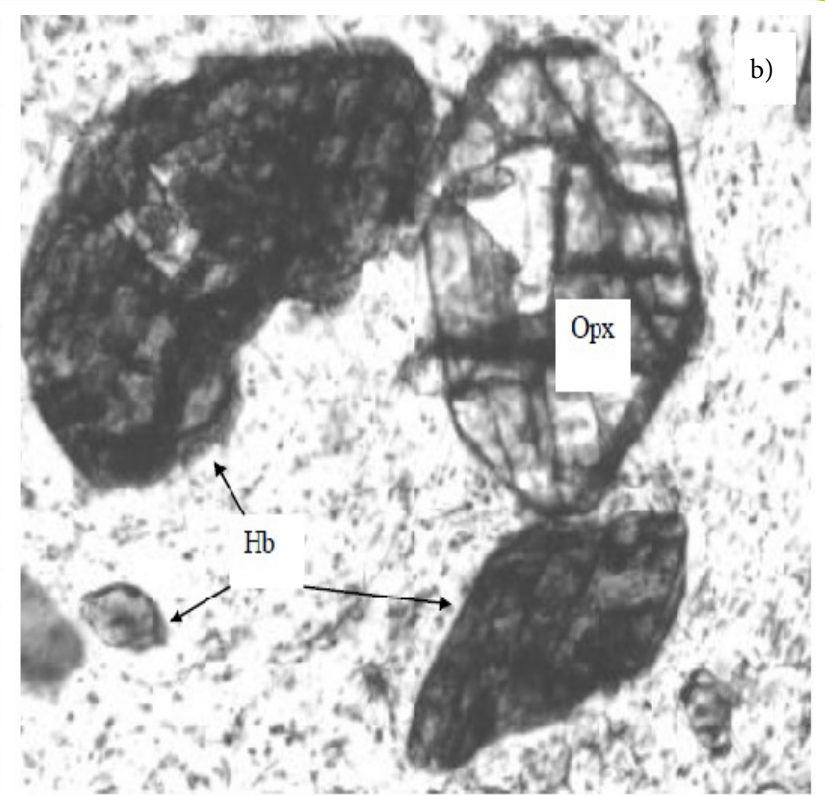

Figure 4: Plagioclase and mafic minerals in Banco Bonito lava flow.

a). Plagioclases are normally zoned and resorbed. Some plagioclases have resorbed cores but glass-free rims.

b). Hornblendes is usually euhedral and occurs as isolated grains in glass. Othorpyroxene is euhedral. 
Citation: Ren M, Parker DF (2019) Composition Variation and Eruption Dynamics of the El Cajete Series, Valles Caldera, New Mexico. Int J Earth Environ Sci 4: 163. doi: https://doi.org/10.15344/2456-351X/2019/163

Page 4 of 12

plagioclase in this unit is less than in ECP and BAT. Clinopyroxenes are usually subhedral and larger than orthopyroxene. Orthopyroxenes are usually euhedral to subhedral, scattered in glass. Biotites are euhedral to subhedral, most of them with hornblende overgrowth. Most hornblendes are usually euhedral and occur as isolated grains in glass (Figure 4b). Quartz generally is anhedral, with resorbed edges.

Crystal aggregates are distributed in BB. Within the aggregates, hornblende mantles the biotite and pyroxene. The plagioclases have cumulate texture. The grain size of minerals in aggregates is smaller than that of single grain.
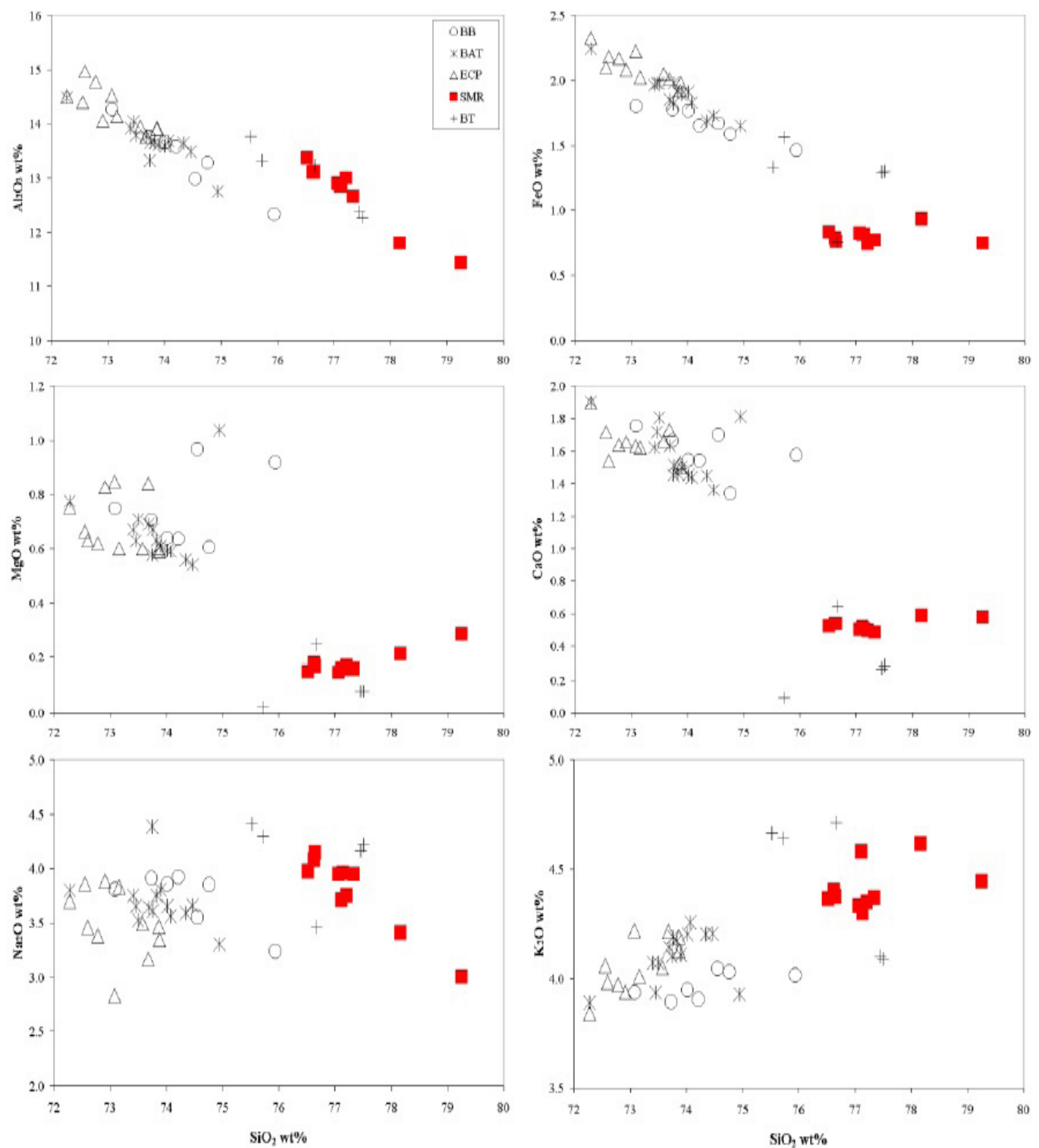

Figure 5: Harker diagrams showing the variation of major elements in ECS, SMR, and BT. The El Cajete series (ECS) has $\mathrm{SiO}_{2}<75 \mathrm{wt} \%$, and shows a general increasing trend for $\mathrm{SiO}_{2}$ from early eruption ECP, to BAT, to later $\mathrm{BB} . \mathrm{Al}_{2} \mathrm{O}_{3}, \mathrm{FeO}, \mathrm{CaO}$ show negative trends while $\mathrm{MgO}, \mathrm{Na}_{2} \mathrm{O}$ and $\mathrm{K}_{2} \mathrm{O}$ show positive trends with increasing $\mathrm{SiO}_{2}$ for $\mathrm{ECS}$. SMR forms trends distinct from those of the ECS. With increasing $\mathrm{SiO}_{2}, \mathrm{Al}_{2} \mathrm{O}_{3}, \mathrm{FeO}$ show negative trends and $\mathrm{K}_{2} \mathrm{O}$ shows a positive trend with different slopes for SMR samples compared to ECS; $\mathrm{MgO}, \mathrm{CaO}$, and $\mathrm{Na}_{2} \mathrm{O}$ for SMR show reverse trends compared to ECS The trends of the Bandelier Tuff are similar to those of the SMR. (BB = Banco Bonito Lava Flow, BAT $=$ Battleship Rock Tuff, ECP = El Cajete Pumice Fall, SMR = South Mountain Rhyolite, and BT = Bandelier Tuff) 
Citation: Ren M, Parker DF (2019) Composition Variation and Eruption Dynamics of the El Cajete Series, Valles Caldera, New Mexico. Int J Earth Environ Sci 4: 163. doi: https://doi.org/10.15344/2456-351X/2019/163

Page 5 of 12

increasing trend for $\mathrm{SiO}_{2}$ from early eruption $\mathrm{ECP}$, to BAT, to later $\mathrm{BB}$. On Harker diagrams (Figure 5), $\mathrm{Al}_{2} \mathrm{O}_{3}, \mathrm{FeO}, \mathrm{CaO}$ show negative trends while $\mathrm{MgO}, \mathrm{Na}_{2} \mathrm{O}$ and $\mathrm{K}_{2} \mathrm{O}$ show positive trends with increasing $\mathrm{SiO}_{2}$ for ECS. The aluminum saturation index $\left(\mathrm{Al}_{2} \mathrm{O}_{3} /\left(\mathrm{CaO}+\mathrm{Na}_{2} \mathrm{O}+\mathrm{K}_{2} \mathrm{O}\right)\right)^{2}$ shows that the ECS is mainly a peraluminous series. Trace elements plotted versus $\mathrm{SiO}_{2}$ show some evolutionary trends with increasing silica (Figure 6). In the El Cajete Series, $\mathrm{Sr}, \mathrm{Ba}$, and $\mathrm{Zr}$ show negative trends with increasing $\mathrm{SiO}_{2} ; \mathrm{Rb}, \mathrm{Nb}$ and $\mathrm{Y}$ have slight positive trends. SMR has different trends compared with those of the ECS.

Rare Earth Element analyses were made for eight samples by INAA (Table 1) (Supplementary File). Within the ECS, REE variation is not so obvious. $\mathrm{ECP}$ and $\mathrm{BB}$ are similar; $\mathrm{BB}$ is slightly richer in HREE. BAT is lower in $\mathrm{La}$, and $\mathrm{Yb}$ (Figure 7). The Eu negative anomaly in BAT is a little smaller than ECP and $\mathrm{BB}$.
Therefore, BAT seems slightly less evolved than ECP and BB. The two SMR samples show higher HREE and a stronger Eu anomaly. The BAT is slightly depleted in $\mathrm{Hf}, \mathrm{Th}, \mathrm{Y}$, and $\mathrm{Nb}$ compared to the rest of ECS.

The ECS shows reversed compositional gradients within the three members. The common pattern of such eruptive sequences is usually to show a progression from most evolved to least evolved magma. $\mathrm{Sr}, \mathrm{Ba}$, and $\mathrm{Zr}$ would show roofward depletion. HREE and HFSE are usually concentrated roofward in zoned eruptions [22]. The earliest eruption (ECP) has lower silica and the latest (BB) has the highest (Figure 6). Trace elements show more detailed change. BB has the lowest $\mathrm{Sr}, \mathrm{Ba}$ and $\mathrm{Zr}$ contents (Figure 8). Incompatible elements (REE, $\mathrm{Th}, \mathrm{Nb}$, and $\mathrm{Hf}$ ) in the BAT are the lowest. Thus, the ECS differs from normal eruptive sequences.
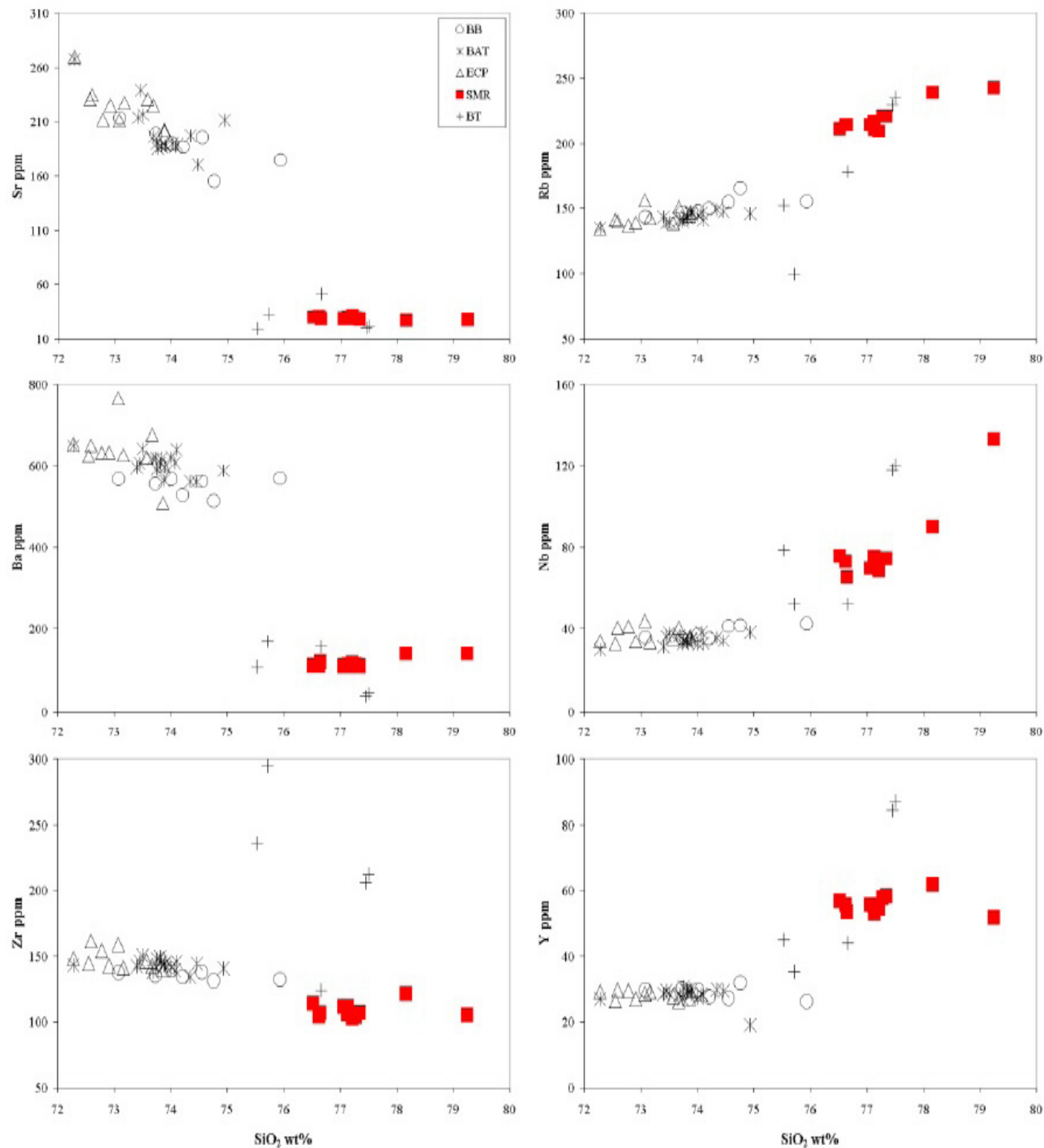

Figure 6: $\mathrm{Sr}, \mathrm{Ba}, \mathrm{Zr}, \mathrm{Rb}, \mathrm{Y}$, and $\mathrm{Nb}$ versus $\mathrm{SiO}_{2}$ showing whole-rock variation between $\mathrm{ECS}, \mathrm{SMR}$, and $\mathrm{BT}$. Sr, $\mathrm{Ba}$, and $\mathrm{Zr}$ show negative trends with increasing $\mathrm{SiO}_{2} ; \mathrm{Rb}, \mathrm{Nb}$ and $\mathrm{Y}$ have slight positive trends in ECS. SMR has different trends compared with those of the ECS. (Symbols as in Figure 6) 
Citation: Ren M, Parker DF (2019) Composition Variation and Eruption Dynamics of the El Cajete Series, Valles Caldera, New Mexico. Int J Earth Environ Sci 4: 163. doi: https://doi.org/10.15344/2456-351X/2019/163

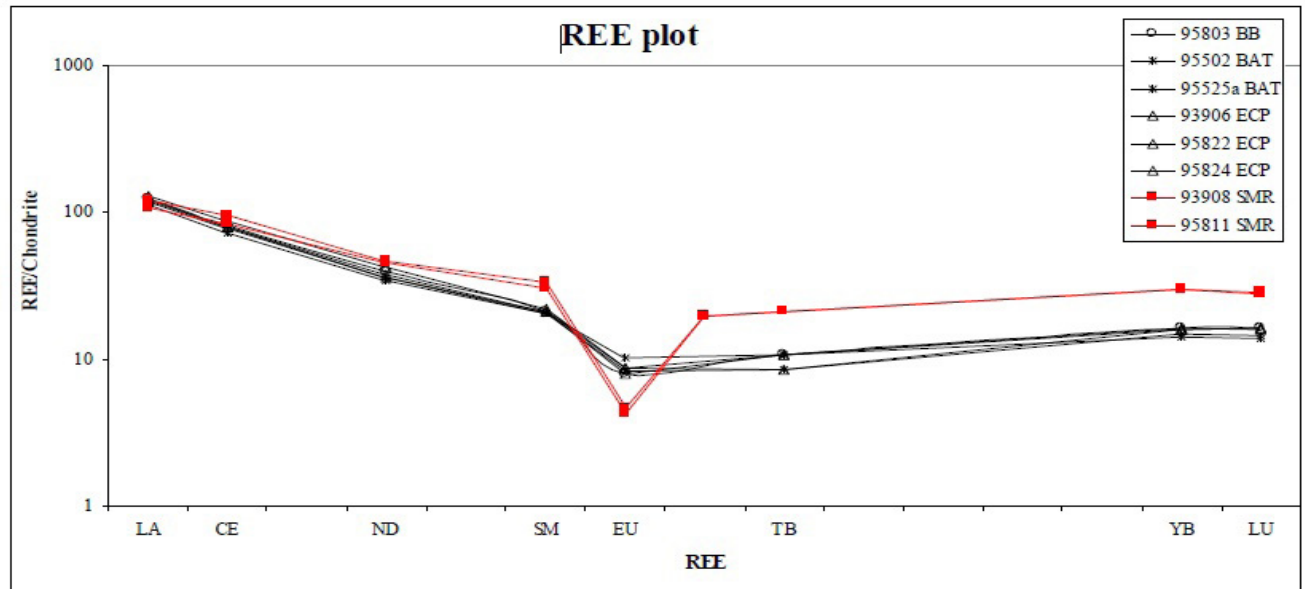

Figure 7: Chondrite normalized REE distribution diagram. (12 Chondrite, symbols as Figure 6. (Note: Gd was not analyzed. Gd values extrapolated from HREE trend [22])
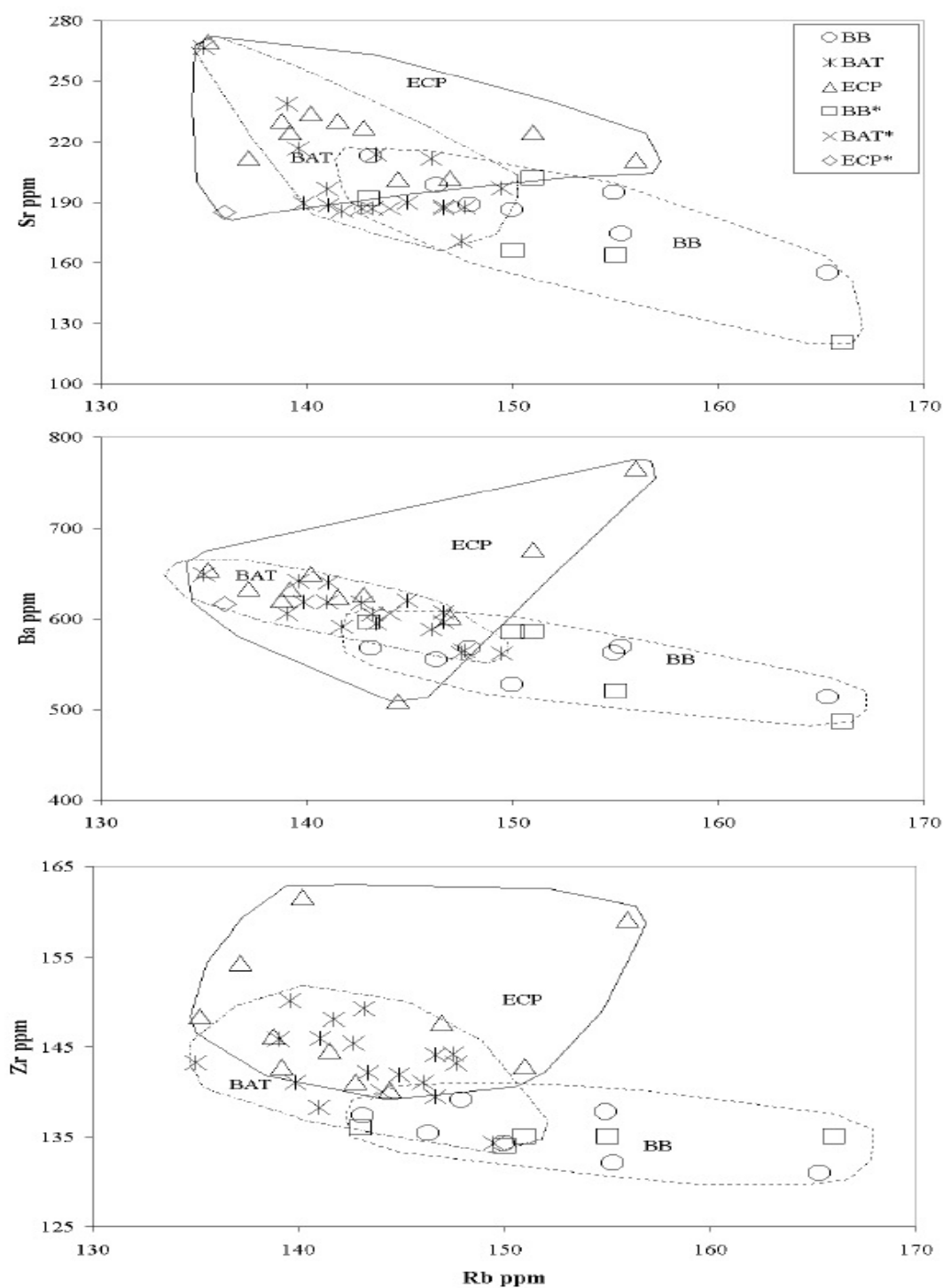

Figure 8: Trace elements plots for ECS showing variations among the three members. BB has lower $\mathrm{Sr}, \mathrm{Ba}$ and $\mathrm{Zr}$ and higher Rb compared to ECP and BAT. (Symbols as in Figure 6. BB*, BAT* and $\mathrm{ECP}^{\star}$ are published data $[16,9,10]$. 
Citation: Ren M, Parker DF (2019) Composition Variation and Eruption Dynamics of the El Cajete Series, Valles Caldera, New Mexico. Int J Earth Environ Sci 4: 163. doi: https://doi.org/10.15344/2456-351X/2019/163

Page 7 of 12

South Mountain Rhyolite and Bandelier Tuff (BT) samples are also plotted on the Harker diagram for comparison (Figure 5). SMR forms trends distinct from those of the ECS. With increasing $\mathrm{SiO}_{2}$, $\mathrm{Al}_{2} \mathrm{O}_{3}, \mathrm{FeO}$ shows negative trends and $\mathrm{K}_{2} \mathrm{O}$ shows a positive trend with different slopes for SMR samples compared to ECS; $\mathrm{MgO}, \mathrm{CaO}$, and $\mathrm{Na}_{2} \mathrm{O}$ for SMR show reverse trends compared to ECS. The trends of the Bandelier Tuff are similar to the SMR. Trace elements for the Bandelier Tuff and SMR are also plotted on Figure 6. Their trends are very similar except that the Bandelier Tuff has higher $\mathrm{Zr}$ than SMR. Therefore, the SMR may be more closely related to the Bandelier Tuff magmatic system, which formed the caldera. According to the geochemical data, SMR and ECS are two different magmatic systems, showing contrasting evolutionary trends.

\section{Resorption texture and hornblende overgrowth in ECS}

Plagioclase is resorbed in all three members of ECS. Resorption is greater in plagioclase of ECP and less in BB. Magma mixing is considered to be a major cause for resorbed volcanic plagioclase, but plagioclase resorption can also occur if plagioclase crystallized at high pressure has become unstable during decreasing pressure accompanying magma ascent [24-26]. Experimental data indicate a systematic increase in albite content of plagioclase with pressure [26]. Plagioclase composition is pressure dependent, decompression causing more calcic plagioclase in equilibrium with liquid and sodic plagioclase dissolution [27]. A model of rapid magmatic decompression has been proposed for plagioclase resorption by Nelson and Montana [27]. The extent of resorption depends on the pressure drop and the re-equilibrium period after the depression.

Zoning of plagioclase is probably a function of cooling rate. Normal zoning in plagioclase could form at the indicated slow rates. With increased cooling rate, the core of plagioclase is more albitic $[28,29]$. Reverse zoned plagioclase can result from supercooling [30,31].

The plagioclase resorption texture in ECS can be the result of magma decompression. Bubbles in the resorbed plagioclase might result from a period of equilibrium degassing and bubble growth and then a rapid magma rise and eruption [32,33]. With rapid rise, the rim of plagioclase presents reversed zoning.

Hornblende usually occurs as jackets surrounding pyroxene and biotite in ECS. The relationship between hornblende and biotite reverses Bowen's discontinuous reaction series. However, biotites may crystallize before amphiboles for silicate melts near alkali feldspar saturation [34]. The $\mathrm{H}_{2} \mathrm{O}$-conservative reaction

$$
\begin{aligned}
& \mathrm{KAlSi}_{3} \mathrm{O}_{8}+\mathrm{Ca}_{2} \mathrm{Mg}_{5} \mathrm{Si}_{8} \mathrm{O}_{22}(\mathrm{OH})_{2}= \\
& \mathrm{KMg}_{3} \mathrm{AlSi}_{3} \mathrm{O}_{10}(\mathrm{OH})_{2}+2 \mathrm{CaMgSi}_{2} \mathrm{O}_{6}+4 \mathrm{SiO}_{2}
\end{aligned}
$$

takes place between 200 and 4000 bars at $755^{\circ} \mathrm{C}$ with phlogopitepyroxene-quartz as high-temperature assemblage [35]. For the reaction

$$
\begin{aligned}
& \mathrm{NaCa}_{2} \mathrm{Fe}_{4} \mathrm{AlSi}_{6} \mathrm{Al}_{2} \mathrm{O}_{22}(\mathrm{OH})_{2}+\mathrm{KAlSi}_{3} \mathrm{O}_{8}+\mathrm{SiO}_{2}= \\
& \mathrm{NaAlSi}_{3} \mathrm{O}_{8}+\mathrm{CaAl}_{2} \mathrm{Si}_{2} \mathrm{O}_{8}+\mathrm{CaFeSi}_{2} \mathrm{O}_{6}+\mathrm{KFe}_{3} \mathrm{AlSi}_{3} \mathrm{O}_{10}(\mathrm{OH})_{2}
\end{aligned}
$$

the free energy is lower on the right hand side [35]. Only at the condition of low activities of $\mathrm{SiO}_{2}$ and $\mathrm{KAlSi}_{3} \mathrm{O}_{8}$ does Bowen's reaction series become the general case [35]. Decreasing thermal stability of amphibole with increasing pressure has been observed [36]. At similar temperatures but with decreasing pressure, the stability of amphibole will increase. Therefore, biotite coexist with pyroxene and biotite crystallized before amphibole has been demonstrated in many volcanic rocks [35,37-39].

\section{Mineral Analysis}

Electron microprobe analyses were performed for most phenocryst phases; representative probe analyses are listed in Table 2 (Supplementary File).

$\mathrm{Mg} /\left(\mathrm{Mg}^{+} \mathrm{Fe}\right)$ for biotite and hornblende in ECS is similar (Figure 9a). They should have crystallized from the same source. For biotite with hornblende overgrowths and isolated biotite grains, the biotite with hornblende overgrowth has higher $\mathrm{Mg} /\left(\mathrm{Mg}^{+} \mathrm{Fe}\right)$ (Figure $\left.9 \mathrm{~b}\right)$. Therefore, they are the products of earlier crystallization. Therefore, the overgrowth of hornblende around pyroxene and biotite in ECS is from a normal crystallizing sequence. The plagioclase, biotite, hornblende aggregates in the rock might have come from the cooling rim of the magma chamber and entangled during the magma ascent.

The $\mathrm{Mg} /\left(\mathrm{Mg}^{+} \mathrm{Fe}\right)$ ratios in biotite and hornblende are totally different between SMR and ECS (Figure 9a), suggesting that SMR and ECS belong to different magmatic systems.

\section{Geothermometry and Geobarometry}

Several geothermometers and geobarometers were used to calculate the temperature and pressure for these units [40] (Table 3, Table 4) (Supplementary File).

Plagioclase for BB mainly falls in the field of andesine $\left(\mathrm{An}_{51-66}\right)$. Alkali feldspar in BB is Na-sanidine. Plagioclase for BAT ranges from oligoclase, andesine, to labradorite. Most of plagioclase in BAT is compositionally zoned. For ECS, both $\mathrm{Ba}$ and $\mathrm{Sr}$ in plagioclase show positive partitioning with increasing whole rock $\mathrm{SiO}_{2}$ [40]. Alkali feldspar plots as K-high albite. Most plagioclases and the rim of zoned plagioclase for SMR are high-oligoclase $\left(\mathrm{An}_{13-17}\right)$. Alkali feldspar of SMR is Na-sanidine $\left(\mathrm{Or}_{57-62}\right)$. Sr and Ba partition into alkali feldspar in both ECS and SMR and show positive correlations with the Or content in the alkali feldspar [41].

Using SOLVCALC 2 [42], a two-feldspar geothermometer program, and the average composition of plagioclase rim and alkali feldspar, different geothermometers give similar results (Table 3) (Supplementary File), the temperature for $\mathrm{BB}$ is $\mathrm{T}=789^{\circ} \mathrm{C}$ [43]; $\mathrm{T}=794$ oC [44]; and $\mathrm{T}=790^{\circ} \mathrm{C}$ [45]. The temperature for SMR is $\mathrm{T}=709$ 711 oC [43]; $\mathrm{T}=678-690^{\circ} \mathrm{C}$ [44]; and $\mathrm{T}=708-720^{\circ} \mathrm{C}$ [45]. The SMR temperature is lower than reported data $\sim 760^{\circ} \mathrm{C}$ for VGM [10]. Using the assumption that the cores of zoned plagioclase were in equilibrium with sanidine, the temperatures for crystallization of plagioclase cores ranged from $800-1000^{\circ} \mathrm{C}[46]$.

Clinopyroxene and orthopyroxene coexist in the $\mathrm{BB}$ and BAT. Clinopyroxene for BB mainly falls in the augite field. Most clinopyroxene in BAT falls within the upper-left of augite field. The orthopyroxene in BB and BAT falls in hypersthene field $\left(\mathrm{En}_{50-77}\right)$.

Using the QUILF95 program [47] and the composition of the average rim of cpx, opx, ilmenite and magnetite, the temperature of BAT is $864-868^{\circ} \mathrm{C}, \log \left(\mathrm{fo}_{2}\right)$ is -10.67 to -10.98 and the temperature for $\mathrm{BB}$ is $834-853^{\circ} \mathrm{C}, \log \left(\mathrm{fo}_{2}\right)$ is -10.95 to -11.11 . Using the two-pyroxene geothermometer to evaluate the difference of temperatures for both clinopyroxene and orthopyroxene [48], the rims of the pyroxene usually gave similar temperatures. Therefore, the temperature from the mineral rim is likely the temperature of magma at its eruption stage. For SMR, QUILF95 for two oxides gives $728-736^{\circ} \mathrm{C}, \log \left(\mathrm{fo}_{2}\right)$ is -14.32 to -15.12 . 

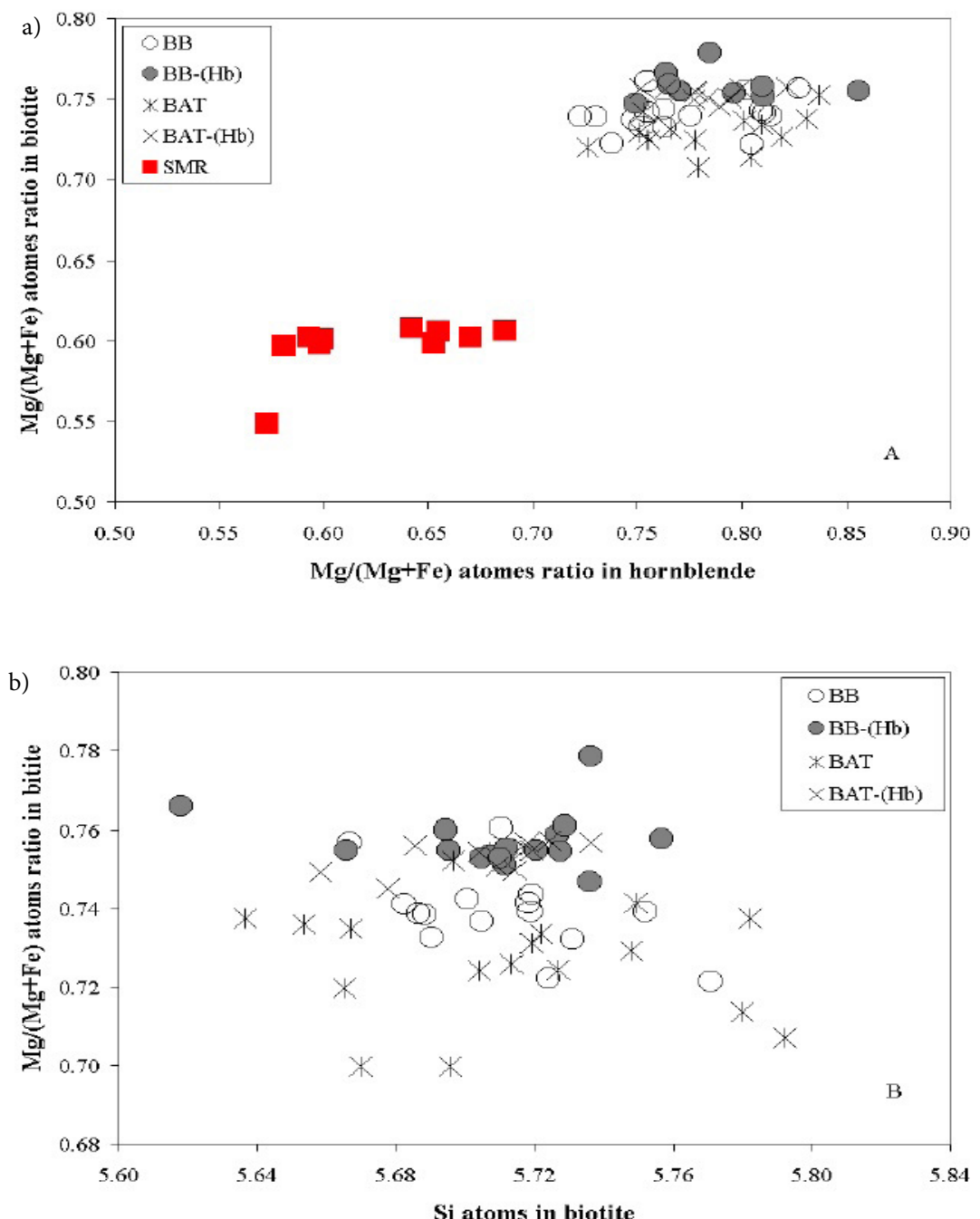

Figure 9: Hornblende and biotite composition.

a) $\mathrm{Mg} /\left(\mathrm{Mg}^{+} \mathrm{Fe}\right)$ for biotite and hornblende in ECS are similar. SMR and ECS have different $\mathrm{Mg} /$ $\left(\mathrm{Mg}^{+} \mathrm{Fe}\right)$ ratios.

b) For biotite with hornblende overgrowth and isolated biotite grains, biotite with hornblende overgrowths has higher $\mathrm{Mg} /\left(\mathrm{Mg}^{+} \mathrm{Fe}\right)$ ratios.

(BB, BAT and SMR are minerals from Banco Bonito Lava Flow, Battleship Rock Tuff, and South Mountain Rhyolite, BAT-( $\mathrm{Hb})$ and BB-( $\mathrm{Hb})$ are biotite with hornblende overgrowth).

Hammarstrom and Zen [49], Hollister and others [50] proposed empirical correlations between the total $\mathrm{Al}$ content of hornblende and the estimated pressures of crystallization of calc-alkaline plutons. The barometer has also been experimentally calibrated using the assemblage of quartz + alkali feldspar + plagioclase + hornblende + biotite + Fe-Ti oxide + melt + fluid [51-53]. Anderson and Smith [54] calibrated the pressure using a revised expression incorporating the effect of temperatures.

Hammarstrom and Zen [49], Hollister and others [50] proposed empirical correlations between the total $\mathrm{Al}$ content of hornblende and the estimated pressures of crystallization of calcalkaline plutons. The correlation is linear:

$$
\begin{aligned}
& \mathrm{P}(+3 \mathrm{kbar})=-3.92+5.03 \mathrm{Al}^{\mathrm{T}} \\
& \text { and } \\
& P(+1 \mathrm{kbar})=-4.76+5.64 \mathrm{Al}^{\mathrm{T}}
\end{aligned}
$$

where $\mathrm{P}$ is pressure in kilobar, and $\mathrm{Al}^{\mathrm{T}}$ is total number of cations of Al per formula unit based on 23 oxygens. Using these two hornblende geobarometers and the composition of hornblende rim, the estimated pressure for SMR is 1.13-1.50 kbar, similar to the reported data 0.5 $1.5 \mathrm{kbar}$ [10]. BAT is in the range 1.57 -- $3.64 \mathrm{kbar}$; BB is $1.96--4.38$ kbar. The barometer has been experimentally calibrated using the assemblage of quartz + alkali feldspar + plagioclase + hornblende + biotite $+\mathrm{Fe}$-Ti oxide + melt + fluid [51-53]. Anderson and Smith [54] calibrated the pressure using a revised expression incorporating the effect of temperatures. The geobarometer from Anderson and Smith [54] yields an average pressure of 1.18-1.33 kbar for SMR, very close to the results from Hammarstrom and Zen [49] and Hollister and others [50]. The high numbers are from Schmidt [53] calculation. The Schmidt barometer was established under a higher experimental condition -- 2.5-13 kbar. The geobarometer from Anderson and Smith [54] is not suitable for the high temperature ECS, because the equation has a 1.3 to $>2 \mathrm{kbar}$ derivation for the high temperature system. 
Citation: Ren M, Parker DF (2019) Composition Variation and Eruption Dynamics of the El Cajete Series, Valles Caldera, New Mexico. Int J Earth Environ Sci 4: 163. doi: https://doi.org/10.15344/2456-351X/2019/163

Page 9 of 12

The geobarometer from Anderson and Smith [54] is not suitable for the high temperature ECS, because the equation has a 1.3 to $>2 \mathrm{kbar}$ derivation for the high temperature system. We chose Hollister and others' [50] empirical Al-in-hornblende barometer as our pressure report: SMR 1.22-1.24 kbars, ECS 2.52-3.68 kbars. The calculated pressures from the different barometers are listed in Table 4 (Supplementary File).

The iron-titanium temperature and two feldspar temperature were the most stable geothermometers in this research. The Iron-titanium thermometer yielded the highest temperatures. The iron-titanium geothermometer and two-feldspar geothermometer have a deviation about $40-60^{\circ} \mathrm{C}$. This is in the allowed range of error; therefore these temperatures are acceptable.

\section{Hypothesis for the generation of ECS}

The three members of the El Cajete Series: the El Cajete Pumice Fall (ECP), Battleship Rock Tuff (BAT), and Banco Bonito Lava Flow (BB) have similar mineral assemblages.
From ECP, BAT to BB, the silica increases by 2 wt.\%. Accordingly, other oxides also show relative changes. The trace elements show complimentary trends. ECP, BAT, and BB have different ranges on Rb$\mathrm{Sr}, \mathrm{Zr}$, and Ba diagrams (Figure 6). For the El Cajete Series, the earliest eruptions (ECP) are less silicic overall and the composition range is widest; the last eruptions (BB) have higher silica. This character is opposite to the general eruption trend expected from a zoned magma chamber. A five-stage model of evolution and eruption for the ECS is presented below (Figure 10) to help explain this compositional inversion and other features of the ECS [55].

At stage I, there is a deep subjacent magma chamber under the southwestern margin of the Valles Caldera. Through fractional crystallization, this magma chamber has developed vertical chemical zonation, with high silica rhyolite at the top overlying lower silica rhyolite. The crystallization temperature for BAT is $828-935^{\circ} \mathrm{C}(\mathrm{Fe}-\mathrm{Ti}$ oxides) and for $\mathrm{BB}$ is $835-925^{\circ} \mathrm{C}$ (Fe-Ti oxides). Ptotal is 3-3.6 kbars for $\mathrm{BAT}$ and 3.3-4.2 kbars for $\mathrm{BB}$ according to the inner rim composition of hornblende. The probable depth of the deeper chamber is $9-11 \mathrm{~km}$.

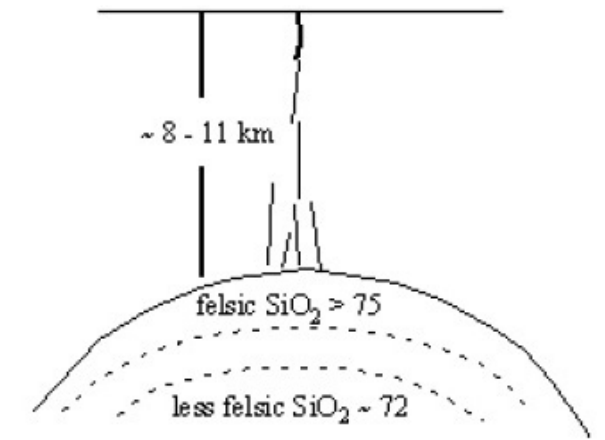

Stage I. Vertical gradients in subjacent chamber through fractional crystallization

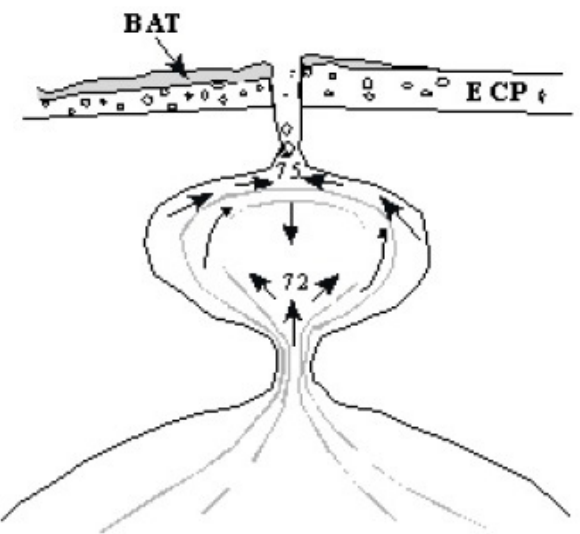

Stage IV. Static period.

\section{Erosion of E CP and BAT}

Figure 10: Hypothetical eruption model for El Cajete Series. Stage I. Vertical gradients in a deep magma chamber. Stage II. Magma intruded into a shallow sub-chamber and causing thinning of the compositional zones in the upper part of the subchamber. Stage III. Eruption of ECP and BAT; the plinian eruption of ECP tapped into the lower less silicic zones. Stage IV. Static period. Erosion of ECP and BAT; the sub-chamber re-established the zonation. Stage V. Eruption of BB lava.
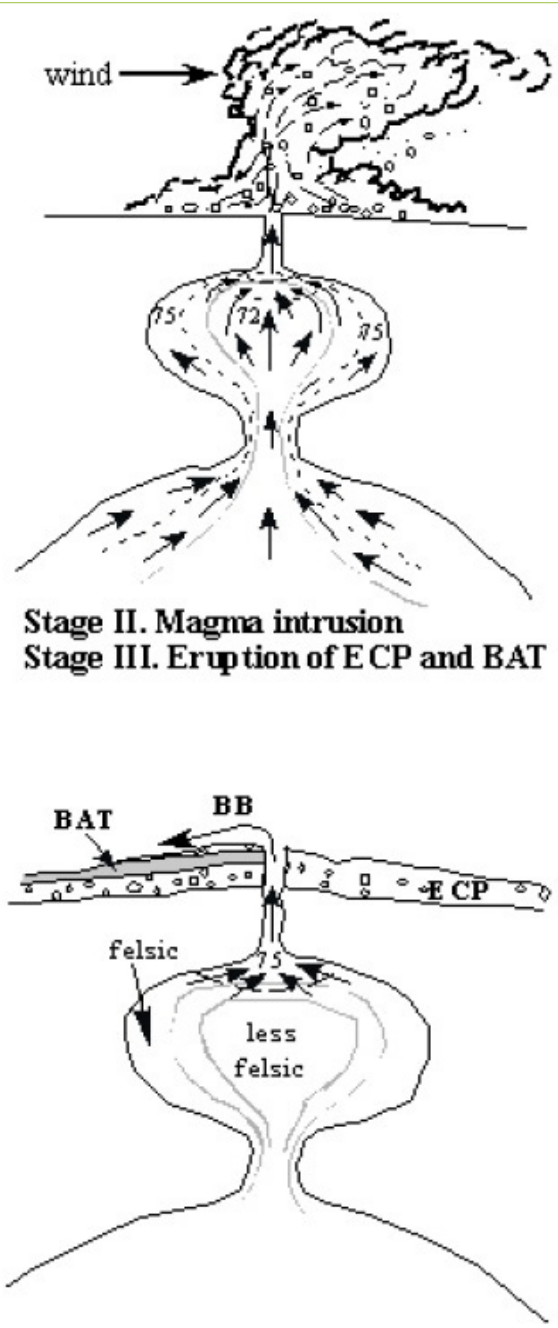

Stage V. Eruption of BB
Int J Earth Environ Sci

ISSN: 2456-351X 
Teleseismic 2-D surveys indicate a low-velocity zone exists in the midcrust beneath the Valles caldera [56-58]. Steck and others [59] reported a low velocity zone in the mid-crust underneath the northwest half of Valles caldera. The depth of low velocities is likely at 7.5 and $12.5 \mathrm{~km}$ (with top deeper than $5 \mathrm{~km}$ and shallower than $15 \mathrm{~km}$ ) [59]. This may be a remnant of the deeper magma chamber proposed in our model.

In stage II, possibly induced by the intrusion of new magma below, the magma of this subjacent chamber is intruded up into a shallowlevel chamber. During the intrusion, the vertical compositional zonation is converted into concentric zonation in the shallow chamber by passage through a narrow, connecting conduit. The intrusion led to some mixing between the adjacent composition zones and also caused lowering of pressure. The resorption of plagioclase, reversed composition zonation of plagioclase and the hornblende overgrowth may be the result of this process. This kind of intrusion has been documented in the Grizzly Peak cauldron, Sawatch Range, Colorado [60]. Because of the push from underneath, the most evolved chemical zones in the shallow chamber became thinner, whereas the same chemical zones on the sides of the chamber became thicker.

Stage III involves eruption of magma to form the ECP and the BAT members. Because of the strong degassing of the magma, these first eruptions are more violent than the later ones [61]. This explosion tapped deep into the shallow chamber; this deep tapping created mixing of the different chemical zones. Initial sub-plinian eruptions formed the largest eruption of the series, the El Cajete Pumice Fall. Then magma from the deeper levels and the sides of the chamber filled up the erupted space. This process mingled magma of different zones, causing the less evolved magma to fill the upper part of the chamber. The following eruption formed the BAT.

Stage IV. After the eruption of Battleship Rock ignimbrite, there was an eruption lull. During this static period, the magma chamber re-equilibrated and more evolved magma pooled in its upper part, reestablishing the normal compositional zonation. In this time, erosion removed some of the upper part of unwelded ignimbrite, thinned the BAT stratum and formed some gullies on the surface of BAT.

Stage V. The magma activated again. This time, a less energetic eruption only tapped the upper portion of the magma chamber. The issued lava formed the more evolved BB. Because the Banco Bonito lava is the uppermost and most evolved magma erupted from the chamber, it has higher silica and $\mathrm{Rb}$, less $\mathrm{Fe}, \mathrm{Ca}, \mathrm{Sr}$, and $\mathrm{Ba}$.

\section{Conclusions}

The youngest eruptions in the Jemez Volcanic field occurred in the southwestern moat of the Valles Caldera. They formed two series: a younger El Cajete series (ECS), erupted at 48-61 Ka and an older South Mountain Rhyolite, erupted at 490-520 Ka.

ECS is rhyolite $\left(\mathrm{SiO}_{2}\right.$ 72.04-75.29 wt\%); ECP has lower $\mathrm{SiO}_{2}$ (72.28-73.88 wt\%), BB has higher $\mathrm{SiO}_{2}(73.08-75.94 \mathrm{wt} \%), \mathrm{BAT}$ is intermediate. Phenocrysts for ECS are plagioclase, clinopyroxene and orthopyroxene, biotite, hornblende, ilmenite, magnetite and a few $\mathrm{Na}$ sanidine in the late stage rocks. The SMR is high-silica rhyolite $\left(\mathrm{SiO}_{2}\right.$ 76.3-79.25 wt \%).
Using the iron-titanium oxides geothermometer basic program from Andersen and Lindsley [62], the average temperature for SMR is $729-773^{\circ} \mathrm{C}$, for $\mathrm{BAT}$ is $832--840^{\circ} \mathrm{C}$; and for $\mathrm{BB}$ temperature is in the range of $822--863^{\circ} \mathrm{C}$.

Two-feldspar geothermometry from different models produced similar results. $\mathrm{BB}$ is around $790^{\circ} \mathrm{C}$. The temperature for SMR is about $700^{\circ} \mathrm{C}$.

The iron-titanium temperature and two feldspar geothermometers were the most stable in this research. The iron-titanium thermometer yielded the highest temperatures. The iron-titanium geothermometer and two-feldspar geothermometer have a deviation about 50-60 oC. This is in the allowed range of error; therefore these temperatures are acceptable.

Pressures for ECS and SMR were calculated from different barometers (Table 4). The results for SMR are close, from 1.18 to $2.19 \mathrm{kbars}$. The results for ECS are in the range of 1.02 to $4.50 \mathrm{kbar}$, suggesting crystallization over an extended pressure/depth range.

Eruption dynamics caused the ECS to have a reverse compositional zonation. With increasing silica in ECP--BAT-- BB, Rb increases, and $\mathrm{Nb}$ slightly increases, whereas the other commonly incompatible elements, such as $\mathrm{Sr}, \mathrm{Ba}$, and $\mathrm{Zr}$, decrease. U/Th dating of raw surfaces of zircon generated multiple ages from 75 to $350 \mathrm{Ka}$, indicating cycling of zircon crystals within the magma chamber [15]. A zoned magma chamber intrusion, mixing and decreasing eruption energy may have caused the inverted eruptive sequence for the El Cajete Series. The eruption of the ECS accompanied by progressive degassing of the magma chamber and declining energy of eruption. The initial plinian or suibplinian eruptions during strong degassing tapped into the deeper part of the magma chamber and caused mixing of different zones. During this eruption, the magma chamber released most of its volatiles. The last eruptions were less energetic. The youngest eruption tapped only the upper part of the magma chamber, which had re-established a normal vertical gradation during an eruption lull, and produced the BB lava, the most evolved part of the ECS.

Intrusion of new magma into the ECS chamber at depth may have triggered the eruption of ECS. Based on the geophysical research, the low-velocity midcrustal zone contains at least $10 \%$ melt and even may correspond to $62 \%-100 \%$ silicic melt [59]. Thus, a new pulse of magma into the midcrustal low velocity zone beneath western of caldera might cause a future eruption in the Valles region.

\section{Acknowledgments}

We wish to thank Cleavy McKnight and the late Don Mullica of Baylor University for early review of this work, and the financial and moral support of the Department of Geology, Baylor University. We also thank the anonymous reviewer for their comments and corrections.

\section{Competing Interests}

The author declare no competing interests exist.

\section{References}

1. Gardner JN, Goff F, Garcia S, and Hagan RC, (1986) Stratigraphic relations and lithologic variations in the Jemez volcanic field, New Mexico. J Geophy Res 91: 1763-1778. 
Citation: Ren M, Parker DF (2019) Composition Variation and Eruption Dynamics of the El Cajete Series, Valles Caldera, New Mexico. Int J Earth Environ Sci 4: 163. doi: https://doi.org/10.15344/2456-351X/2019/163

Page 11 of 12

2. Doell RR, Dalrymple GB, Smith RL, Bailey RA (1968) Paleo-magnetism potassium-argon ages, and geology of rhyolites and associated rocks of the Valles caldera. Geol. Soc Am Mem 116: 211-248.

3. Smith RL, and Bailey RA (1968) Resurgent cauldrons. Geol Soc Am Mem 116: 613-662.

4. Izett GA, Obradovich JD, Naeser CW, and Cebula GT (1981) Potassiumargon and fission-track zircon ages of Cerro Toledo rhyolite tephra in the Jemez Mountains, New Mexico. U. S. Geol Surv Prof Pap 1199: 37-43.

5. Spell TL, Harrison TM, and Wolff JA (1990) 40Ar/39Ar dating of the Bandelier Tuff and San Diego Canyon ignimbrites: Temporal constraints on magmatic evolution. J Volc Geotherm Res 43: 175-193.

6. Spell TL, McDougall I, and Doulgeris AP (1996) Cerro Toledo rhyolite Jemez Volcanic field, New Mexico: 40Ar/39Ar geochronology of eruptions between two caldera-forming events. Geol Soc Am Bull 108: 1549-1566.

7. Chapin CE, Wilks M, and McIntosh WC (2004) Space-time patterns of Late Cretaceous to present magmatism in New Mexico-comparison with Andean volcanism and potential for future volcanism: New Mexico Bureau of Geology and Mineral Resources. Bulletin 160: 13-40.

8. Griggs RL (1964) Geology and groundwater resources of the Los Alamos area, New Mexico. U. S. Geol. Surv. Water Supply Pap. 1753, 105 p.

9. Spell TL, and Kyle PR (1989) Petrogenesis of Valle Grande Member rhyolite Valles Caldera, New Mexico: Implications for evolution of the Jemez Mountains magmatic system. J Geophys Res 94: 10379-10396.

10. Spell TL, and Harrison $\mathrm{TM}(1993){ }^{40} \mathrm{Ar} /{ }^{39} \mathrm{Ar}$ geochronology of Post-Valles Caldera Rhyolites, Jemez Volcanic Field, New Mexico. J Geophys Res 98 8031-8051.

11. Toyoda S, Goff F, Ikeda S, and Ikeya M (1995) ESR dating of quartz phenocrysts in the El Cajete and Battleship Rock Members of Valles Rhyolite, Valles Calsera, New Mexico. J Volc Geotherm Res 67: 29-40.

12. Reneau SL, Gardner JN, and Forman SL (1996) New evidence for the age of the youngest eruptions in the Valles caldera, New Mexico. Geology 24 7-10.

13. Wolff JA, and Gardner JN (1995) Is the Valles Caldera entering a new cycle of activity? Geology 23: 411-414.

14. Goff F, and Gardner JN (2004) Late Cenozoic geochronology of volcanism and mineralization in the Jemez Mountains and Valles caldera, north centra New Mexico. In: Mack, G.H., Giles, K.A. (Eds.), New Mexico Geological Society. Special vol. 11: pp. 295-312.

15. Zimmerer MJ, Lafferty J, Coble MA (2016) The eruptive and magmatic history of the youngest pulse of volcanism at the Valles caldera: Implications for successfully dating late Quaternary eruptions. J Volcanol Geotherm Res 310: $50-57$

16. Self S, Kircher DE, and Wolff JA (1988) The El Cajete Series, Valles Caldera, New Mexico. J Geophys Res 93: 6113-6127.

17. Self S, Wolff JA, Spell TL, Skuba CE, and Morrisey MM (1991) Revisions to the stratigraphy and volcanology of the post- $0.45 \mathrm{Ma}$ units and the volcanic section of VC-1 corehole, Valles caldera, New Mexico. J Geophys Res 96 4107-4116.

18. Kelley SA, McIntosh WC, Goff F, Kempter KA, Wolff JA, Esser R, Braschayko S, Love D, Gardner J (2013) Spatial and temporal trends in pre-caldera Jemez Mountains volcanic and fault activity. Geosphere 9: 614-646.

19. Carey S, and Sparks RSJ (1986) Quantitative models of the fallout and dispersal of tephra from volcanic eruption columns. Bull Volc 48: 109-125.

20. Wolff JA, Brunstad KA, Gardner JN (2011) Reconstruction of the most recent volcanic eruptions from the Valles caldera, New Mexico. J Volcanol Geotherm Res 199: 53-68.

21. Kidman M (1983) Late Pleistocene volcanism in the upper canyon de San Diego area, Jemez Mountains, Northern New Mexico. Bachelor's thesis, Baylor Univ., Waco

22. Hildreth W (1981) Gradients in silicic magma chamber: Implications for lithospheric magmatism. J Geophy Res 86: 10153-10192.

23. Wakita H, Rey P, and Schmitt RA (1971) Abundances of the 14 rare-earth elements and 12 other trace elements in Apollo 12 samples: five igneous and one breccia rocks and four soils. Proc. 2nd Lunar Science Conf., 13191329.

24. Johannes $\mathrm{W}$ (1978) Melting of plagioclase in the system Ab-An-H2O and $\mathrm{Qz}-\mathrm{Ab}-\mathrm{An}-\mathrm{H}_{2} \mathrm{O}$ at $\mathrm{fH}_{2} \mathrm{O}=5 \mathrm{kbars}$, an equilibrium problem. Contrib Mineral Petrol.66: 295-303

25. Hattori $K$, and Sato $H$ (1996) Magma evolution recorded in plagioclase zoning in 1991 Pinatubo eruption products. Am Min 81: 982-994.
26. Nash BP, Hausel WD (1973) Partial pressures of oxygen, phosphorus and fluorine in some lunar lavas. Earth and Planetary Science Letters.

27. Nelson ST, Montana A (1992) Sieve-textured plagioclase in volcanic rocks produced by rapid decompression. American Mineralogist 77: 1242-1249.

28. Hopper RW, Uhlmann DR (1973) Effects of electric fields on spinodal decomposition. Physics and Chemistry of Glasses 14: 37-44.

29. Lofgren G (1980) Experimental studies on the dynamic crystallization of silicate melts. Princeton University.

30. Lofgren $\mathrm{G}$ (1974) An experimental study of plagioclase crystal morphology isothermal crystallization Am J Sci 274: 243-273.

31. Stamatelopoulou-Seymour K, Vlassopoulos D, Pearce Th, Rice C (1990) The record of magma chamber processes in plagioclase phenocrysts at Thera Volcano, Aegean Volcanic Arc, Greece. Contributions to Mineralogy and Petrology 104: 73-84.

32. Proussevitch AA, Sahagian DL (1996) Dynamics of coupled diffusive and decompressive bubble growth in magmatic systems. JGR Solid Earth 101 17447-17455

33. Liu Y, Zhang YX (2000) Bubble growth in rhyolitic melt. Earth Plane Sci Lett 181: 251-64.

34. Naney MT, Swanson SE (1980) The effect of Fe and Mg on crystallization in granitic systems. American Mineralogist 65: 639-653.

35. Wones DR, Gilbert MC (1982) Amphiboles in the igneous environment In Reviews in Mineralogy, 9B. Amphiboles Petrology and Experimental Phase Relations, Veblen DR and Ribbe PH, PP. 355-90. Washington, DC; Mineralogical Society of America.

36. Skjerlie KP, and Johnston AD (1996) Vapor-absent melting of crustal rocks. J Petrol 37: 672-691.

37. Ransome FL (1898) Some lava flows of the western slope of the sierra, Nevada, Carlifornia

38. Robinson P, Spear FS, Schumacher JC Laird J Klein C Evans BW and Doolan $\mathrm{BL}$ (1982) In Veblen DR, and Ribbe PH, (eds.), Reviews in Mineralogy, 9B, 'Amphiboles: Petrology and experimental phase relations' Phase relations of metamorphic amphiboles: Natural occurrence and theory, p. 1-229.

39. Wyllie PJ, and Wolf MB (1993) Amphibole dehydration-melting: sorting out the solids, In Prichard, H. M., Alabaster, T., Harris, N.B.W. and Neary, C.R. (eds.), Geol. Soc. Spec. Public. 76, 'Magmatic Processes and Plate Tectonics', pp. 405-416.

40. Ren M, Parker DF, and White JC (2003) Partitioning of $\mathrm{Sr}, \mathrm{Ba}, \mathrm{Rb}, \mathrm{Y}$, and LREE between plagioclase and peraluminous silicic magma. Am. Min., 88: 1091-1103.

41. Ren M (2004) Partitioning of $\mathrm{Sr}, \mathrm{Ba}, \mathrm{Rb}, \mathrm{Y}$, and LREE between alkali feldspar and peraluminous silicic magma. Am Min 89: 1290-1303.

42. Wen (1996) The program SOLVCALC 2, http:\\sbmp96.ess.sunysb.edu SolvCalc.

43. Elkins LT, and Grove TL (1990) Ternary feldspar experiments and thermodynamic models. Am. Min. 75: 544-559.

44. Lindsley $\mathrm{DH}$, and Nekvasil $\mathrm{H}$ (1989) A ternary feldspar model for all reasons. EOS Trans., AGU, 70: 506.

45. Fuhrman $M L$, and Lindsley DL (1988) Ternary-feldspar modeling and thermometry. Am Min 73: 201-215.

46. Ren M (1997) Composition variation within and eruption dynamics of the El Cajete Series, Valles Caldera, New Mexico. Master thesis, Baylor Univ. Waco.

47. Andersen DJ, Lindsley D, Davidson PM (1993) QUILF: A PASCAL program to assess equilibria among Fe-Mg-Mn-Ti oxides, pyroxenes, olivine, and quartz. Computers and Geosciences 19: 1333-1350.

48. Lindsley DH (1983) Pyroxene thermometry. Am Min 68: 477-493.

49. Hammarstrom JM, and Zen E-an (1986) Aluminum in hornblende: an empirical igneous geobarometer. Am Min 71: 1297-1313.

50. Hollister LS, Grissom GC, Peters EK, Stowell HH, Sisson VB (1987) Confirmation of the empirical correlation of $\mathrm{Al}$ in hornblende with pressure of solidification of calc-alkaline plutons. Am Min 72: 231-239.

51. Johnson MC, and Rutherford MJ (1989) Experimental calibration of the aluminum-in-hornblende geobarometer with application to Long Valley caldera (California). Geology 17: 837-841.

52. Thomas WM and Ernst WG (1990) The aluminum content of hornblende in calc-alkaline granitic rocks: A mineralogic barometer calibrated experimentally to 12 kbars. In R. J. Spencer and I-M Chou, (eds.), Geochem. Soc. Spec. Public. 2, 'Fluid-mineral interactions: A tribute to H. P. Eugster'. pp. 59-63. 
Citation: Ren M, Parker DF (2019) Composition Variation and Eruption Dynamics of the El Cajete Series, Valles Caldera, New Mexico. Int J Earth Environ Sci 4: 163. doi: https://doi.org/10.15344/2456-351X/2019/163

Page 12 of 12

53. Schmidt MW (1992) Amphibole composition in tonalite as a function of pressure: An experimental calibration of the Al-in-hornblende barometer. Contrib Mineral Petrol 111: 266-268.

54. Anderson JL, and Smith DR (1995) The effects of temperature and fO2 on the Al-in-hornblende barometer. Am Min 80: 549-559.

55. Ren $M$, and Parker DF (1997) Eruption dynamics and the origin of inverted compositional gradients within the El Cajete Series, Valles Caldera, New Mexico. Abstr with programs Geol Soc Am 30: 571.

56. Baldridge WS, Olsen KH, and Callender JF (1984) Rio Grande rift--Problems and perspectives. In Baldridge, W. S.; Dickerson, P. W.; Riecker, R. E.; Zidek J.; [eds.], Rio Grande Rift (Northern New Mexico), New Mexico Geological Society 35th Annual Fall Field Conference Guidebook, pp. 1-12.

57. Roberts PM, Aki K, and M. C. Fehler MC (1991) A low-velocity zone in the basement beneath Valles caldera, New Mexico, J Geophys Res 96: 2158321596.

58. Lutter WJ, Roberts PM, Thurber CH, Steck LK, Fehler MC, Stafford DG, Baldridge WS, and Zeichert TA (1995) Teleseismic P-wave image of crust and upper mantle structure beneath Valles caldera, New Mexico: Initial results from the 1993 JTEX passive array, Geophys Res Lett 22: 505-508, 1995.

59. Steck LK, Thurber CH, Fehler MC, Lutter WJ, Roberts PM, Baldridge WS, Stafford D, and Sessions R (1998) Crust and upper mantle P wave velocity structure beneath Valles caldera, New Mexico: Results from the Jemez teleseismic tomography experiment. J Geophys Res 103: 24301-24320.

60. Fridrich CJ, and Mahood GA (1984) Reverse zoning in the resurgent intrusions of the Grizzly Peak cauldron, Sawatch Range, Colorado. Geol Soc Am Bull 95: 779-787.

61. Walker GPL (1985) Ignimbrite types and ignimbrite problems. J Volc Geotherm Res 17: 157-171.

62. Andersen DJ, and Lindsley DH (1988) Internally consistent solution models for Fe-Mg-Mn-Ti oxides: Fe-Ti oxides. Am Min 73: 714-726. 